\title{
Melatonin Synergizes the Chemotherapeutic Effect of Cisplatin in Ovarian Cancer Cells Independently of MT1 Melatonin Receptors
}

\author{
AGATA ZEMŁA ${ }^{1}$, IRMINA GRZEGOREK ${ }^{1}$, PIOTR DZIĘGIEL ${ }^{1,2}$ and KAROLINA JABŁOŃSKA ${ }^{1}$ \\ ${ }^{1}$ Department of Histology and Embriology, Wroclaw Medical University, Wroclaw, Poland; \\ ${ }^{2}$ Department of Physiotherapy, University School of Physical Education, Wroclaw, Poland
}

\begin{abstract}
Background/Aim: Melatonin (MLT), through the interaction with membrane melatonin receptors $M T 1$, can improve the effectiveness of cytostatic agents, including cisplatin (CP). The aim of this study was to examine the synergistic effect of MLT and CP in three cell lines: IOSE 364, SK-OV-3 and OVCAR-3, as well as to assess the role of MT1 receptors in this mechanism. Materials and Methods: Using the SRB assay we investigated the effect of different concentrations of $C P$ and MLT on cell viability. Tests, using luzindole - MT1 inhibitor, allowed us to assess the potential involvement of MT1 in the mechanism of MLT action. Results: MLT at certain concentrations demonstrated a synergistic effect in combination with CP. The addition of luzindole did not affect the action of MLT in combination with CP. Conclusion: In summary, the synergistic effect of MLT with CP seems to be independent of membrane MT1 receptors.
\end{abstract}

Ovarian cancer ranks sixth among female cancers and is one of the main causes of death in women (1). Each year this type of cancer affects twenty-five thousand female inhabitants of Western Europe, mostly over 55 years of age. Studies prove that it is more common in older, Caucasian women with high material status, who had never given birth. According to the SEER (The Surveillance, Epidemiology, and End Results program of the National Cancer Institute) in 2016 in the United States about 22,280 new cases of this

This article is freely accessible online.

Correspondence to: Piotr Dzięgiel, Department of Histology and Embriology, Wroclaw Medical University, Poland. Tel: +48 0717840081, Fax: +48 0717840082, e-mail: piotr.dziegiel@ umed.wroc.pl

Key Words: Melatonin, cisplatin, ovarian cancer, chemotherapy, MT1 melatonin receptor. cancer were registered. Despite advances in medicine, precise surgical techniques and modern cytostatic drugs, treatment outcomes continue to be poor. In advanced stages of ovarian cancer, chemotherapy based on cis- and carboplatin is recommended, but because of the serious sideeffects and resistance of cancer cells, it has a limited therapeutic efficacy $(1,2)$. Several experiments suggest that melatonin (MLT) may be a compound improving the effectiveness of chemotherapeutic drugs, including cisplatin (CP) $(1,2)$.

MLT is a pineal hormone that mainly regulates the circadian rhythm of the human (3). Furthermore it may also have anticancer properties in many types of cancers including ovarian cancer (2). MLT has a remarkable pleiotropy of action (4). It takes part in many physiological processes, including the regulation of the circadian rhythm, the immune system, hematopoiesis, and scavenging of free radicals $(5,6)$.

According to previous reports, one of the main mechanisms underlying the antitumor activity of MLT is a direct binding to melatonin membrane receptors. Two subtypes of membrane receptors have been identified in mammals: MT1 and MT2 $(6,7)$. Both belong to the G protein-coupled receptor superfamily (7-9). Activation of MT1 receptor in tumor cells inhibits cAMP production, resulting in a decrease of protein kinase A (PKA), a decrease in phosphorylation of the CREB transcription factor, and consequently affects the expression of genes involved in the proliferation, migration, or angiogenesis processes (10-12).

The MT1 receptor is differently stimulated by the physiological (pico- and nanomolar) and pharmacological (micro- and millimolar) concentrations of MLT. Research to date suggests that the ability to bind MLT to MT1 receptor depends on hormone concentration, exposure time and type of cells $(11,13,14)$. Genetic and immunohistochemistry studies indicate that the MT1 receptor is commonly expressed in the human body $(11,15-17)$, as well as in many types of tumor cells, including ovarian cancer cells (18-22). The exact mechanism of action of MLT, as an adjuvant agent 
supporting chemotherapy and the involvement of MT1 receptors in this process is not fully understood. The literature indicates that MT1 receptor expression levels in tumor cells may be modulated during cancer tumor progression, possibly due to changes in the degree of cell differentiation $(4,21)$.

Due to the high amphipathic properties of the MLT and its ability to penetrate into the cell, it is possible that the mechanism of action of MLT is independent of membrane receptors, such as binding to nuclear receptors i.e. $\mathrm{RZR} / \mathrm{ROR} \alpha$ and RZR $\beta$, affect the expression of genes that play an important role in cell proliferation (23). Additionally, the non-receptor activity of MLT is its ability to bind to calmodulin directly. MLT binding to calmodulin causes its degradation, which in consequence inhibits the cell cycle. Furthermore, MLT is a powerful antioxidant. It prevents the formation of DNA damage by neutralizing free radicals and increasing the activity of antioxidant enzymes such as superoxide dismutase or glutathione peroxidase (24-26).

In vitro studies indicate the various effects of MLT on different cell lines. The few reports about the anticancer activity of MLT in ovarian cancer are also inconsistent. In the human ovarian adenocarcinoma line BG1, it was demonstrated that MLT at nanomolar concentrations reduced cell growth by $20-25 \%$ (27). MLT activities were also examined in an in vitro model in combination with CP (2, 28 ). Both substances synergistically inhibited the viability of SK-OV-3 tumor cells. An inverse relationship was observed in normal epithelial cells (IOSE 364), where the MLT showed a protective effect against $\mathrm{CP}$-induced cytotoxicity (2). In addition, Treeck et al. demonstrated the MT1 receptor expression in ovarian cancer lines SK-OV-3 and OVCAR-3 (20). MT1 receptor expression was significantly higher in the SK-OV-3 line than in the OVCAR-3 line, and treatment with MLT increased expression of the MT1 receptor in both lines. Despite the use of various experimental conditions, no effect of MLT on the growth of the investigated lines was observed. Melatonin signal transduction pathways in cancer cells have not been definitively defined (29).

Based on current literature, the aim of this paper was to investigate the potential synergistic effect of MLT with CP on three cell lines: the line of normal ovarian epithelium IOSE 364, the lines of ovarian cancer SK-OV-3 and OVCAR-3 and assessment of the role of MT1 receptors in this mechanism.

\section{Materials and Methods}

Cell lines. The study material consisted of three cell lines: the normal ovarian epithelial line IOSE 364 and ovarian carcinoma lines SK-OV-3 and OVCAR-3. The IOSE 364 cell line was obtained from the Canadian Ovarian Tissue Bank (Vancouver, Canada) courtesy of Professor Nelly Auersperg. The cells of this line were derived from immortalized normal ovarian epithelial cells. The SK-
OV-3 cell line was purchased from the ECACC (European Collection of Cell Cultures) (Salisbury, UK). This line is derived from ovarian adenocarcinoma and is characterized by moderate aggressiveness. The OVCAR-3 cell line was purchased from LGC Standards/ATCC (American Type Culture Collection, Middlesex, UK). This line is derived from ovarian adenocarcinoma and is characterized by high aggressiveness (30).

IOSE line 364 was cultured in the medium MCDB 105, and 199 (Sigma, Munich, Germany), at a 1: 1 ratio enriched with 5\% FBS (Lonza, Basel, Switzerland). The SK-OV-3 line was cultured in McCoy's 5A Medium (Sigma, Munich, Germany), enriched with $15 \%$ FBS (Lonza). OVCAR-3 line was cultured in Dulbecco's Modified Eagle's Medium (Lonza) supplemented with 15\% FBS (Lonza) and $0.01 \mathrm{mg}$ insulin/ml (Sigma). Additionally, media were supplemented with $1 \% \mathrm{~L}$-glutamine, penicillin and streptomycin (Sigma). The cultures were made at $37^{\circ} \mathrm{C}$ in $5 \% \mathrm{CO}_{2}$.

Compounds. MLT (Sigma, Munich, Germany) was dissolved in a solution of $96 \%$ ethyl alcohol. The MLT output solution was diluted with the culture medium in order to obtain the following concentrations: $0.1 \mathrm{mM}, 0.5 \mathrm{mM}, 1 \mathrm{mM}$ and $2 \mathrm{mM}$. MLT tests were performed with maximum light reduction. A solution of cisplatin (Teva, Haarlem, Netherlands) with an output concentration of $1 \mathrm{mg} / \mathrm{ml}$ was diluted with a culture medium to obtain the following concentrations: $0.5 \mu \mathrm{g} / \mathrm{ml}, 2.5 \mu \mathrm{g} / \mathrm{ml}$ and 5 $\mu \mathrm{g} / \mathrm{ml}$. Luzindol (Sigma) was dissolved in DMSO (Sigma). In order to obtain the concentrations of luzindole $(1 \mu \mathrm{M}, 10 \mu \mathrm{M}$ and $50 \mu \mathrm{M})$, the output solution of luzindole was diluted with a culture medium. Pre-incubation with luzindole lasted $30 \mathrm{~min}$ (before incubation with MLT).

SRB test. Tested cells were seeded with 10,000 per well in a volume of $100 \mu \mathrm{l}$ medium on 96-well culture plates. Cells were incubated with the tested compounds for $72 \mathrm{~h}$. Subsequently, cells were fixed with cold $50 \%$ trichloroacetic acid (TCA) solution $(30 \mu \mathrm{l}$ per $100 \mu \mathrm{l}$ medium) at $4^{\circ} \mathrm{C}$ for $1 \mathrm{~h}$. Cells fixed in the wells were rinsed in water to remove TCA and medium. Then the plates were air dried. After drying, $50 \mu \mathrm{l}$ of a $0.4 \%$ solution of SRB dissolved in $1 \%$ acetic acid solution was added to the wells and incubated for $30 \mathrm{~min}$ at RT. Plates were washed 4 times in $1 \%$ acetic acid and then dried. $150 \mu \mathrm{l}$ of a $10 \mathrm{mM}$ Tris solution was added to the wells and incubated for $30 \mathrm{~min}$ at room temperature. Measurements of absorbance were made at $562 \mathrm{~nm}$ using Infinite M200 microplate reader (TECAN, Morrisville, NC, USA). The test was performed in triplicate.

Coefficient of Drug Interaction (CDI). To evaluate the mechanism of inhibition of survival of tested cells by MLT in combination with CP Coefficient of Drug Interaction (CDI) was used (5): CDI= $\mathrm{AB} / \mathrm{A} * \mathrm{~B}(\mathrm{AB}$-ratio of the absorbance after using the MLT and CP combination to the absorbance of the control group, not treated with any compound, at $562 \mathrm{~nm}$; A - ratio of the absorbance after using the MLT to the absorbance of the control group, not treated with any compound, at $562 \mathrm{~nm}$; B - ratio of the absorbance after using the $\mathrm{CP}$ to the absorbance of the control group, not treated with any compound, at $562 \mathrm{~nm}$ ). CDI value: $<1$ synergistic action, =1 additive action, $>1$ antagonistic action.

Statistical analysis. All experiments were performed at least three times. Data collected were averaged and expressed as mean \pm standard deviation (s.d.). For statistical analysis the student's 
$t$-test, preceded by the normality test (Shapiro-Wilka) and the homogeneity of variance (Levene) or the Mann-Whitney $U$-test, in the case of the absence of normality and homogeneity of variance (non-parametric equivalent of Student's $t$-test) were used. Statistically significant results were considered for which the probability of a first-kind error was $p<0.05$. Statistical analysis was performed using Statistica 10 (StatSoft, Poland).

\section{Results}

Survival evaluation of IOSE 364, SK-OV-3 and OVCAR-3 cells treated with MLT. Tested cell lines showed a MLT dosedependent decrease of cell survival (Figure 1). In line 364 IOSE the lowest percentage of live cells $(61 \pm 5.8 \%)$ was observed after incubation with MLT at a concentration of $2 \mathrm{mM}$. In the SK-OV-3 line there was a slight influence of the concentrations of MLT $(0.1 \mathrm{mM}, 0.5 \mathrm{mM}, 1 \mathrm{mM}, 2 \mathrm{mM})$ on cell survival (mean survival of $98 \%$ ). In the OVCAR-3 line, the lowest cell survival was observed with the highest concentration of MLT $(2 \mathrm{mM})$ and was $74 \% \pm 9.5$. Statistical analysis showed a statistically significant $(p<0.001)$ influence of MLT at a concentration of $0.5 \mathrm{mM}$ on the reduction of IOSE 364 and OVCAR-3 cell survival, and the reduction of SK-OV-3 cell survival at the two highest concentrations of MLT: $1 \mathrm{mM}$ and $2 \mathrm{mM}$.

Survival evaluation of IOSE 364, SK-OV-3 and OVCAR-3 cells treated with MLT in combination with $C P$. In order to investigate the effect of MLT in combination with CP on the survival of the tested cell lines, four concentrations of MLT (0.1 mM, $0.5 \mathrm{mM}, 1 \mathrm{mM}, 2 \mathrm{mM})$ and three concentrations of $\mathrm{CP}(0.5 \mu \mathrm{g} / \mathrm{ml}, 2.5 \mu \mathrm{g} / \mathrm{ml}, 5 \mu \mathrm{g} / \mathrm{ml})$ were used. The experiment compared the viability of the cells after using $\mathrm{CP}$ alone and after the combination of diffrent concentrations of CP with MLT.

$\mathrm{CP}$ at a concentration of $0.5 \mu \mathrm{g} / \mathrm{ml}$ (therapeutic dose (29)) did not significantly decrease the survival of the tested cell lines relative to the control line (KK) (Figure 2). The addition of CP $(0.5 \mu \mathrm{g} / \mathrm{ml})$ to the lowest MLT concentration of $0.1 \mathrm{mM}$ reduced the survival of IOSE 364 and OVCAR3 cells in comparison with $\mathrm{CP}$ alone $(0.5 \mu \mathrm{g} / \mathrm{ml})$. In the case of SK-OV-3 a slight decrease of survival was observed for the combination of CP $(0.5 \mu \mathrm{g} / \mathrm{ml})$ with MLT at a concentration of $0.5 \mathrm{mM}$. Higher concentrations of MLTs used with CP $(0.5 \mu \mathrm{g} / \mathrm{ml})$ resulted in a further, significant $(p<0.001)$ decrease of cell viability compared to CP alone $(0.5 \mu \mathrm{g} / \mathrm{ml})$ in all tested cell lines. The lowest cell survival was observed for the combination of $\mathrm{CP}(0.5 \mu \mathrm{g} / \mathrm{ml})$ with MLT at concentrations of $1 \mathrm{mM}$ and $2 \mathrm{mM}$. The percentages of live cells for these concentrations were for the IOSE 364 line: $80 \% \pm 8.1$ and $55 \% \pm 7.6$, respectively, and for the OVCAR-3 line: $89 \% \pm 6.1 \%$ and $74 \% \pm 8.1$, respectively. SKOV-3 cells responded poorly to the concentrations of tested compounds and their mean survival was $98 \%$.
Increasing the concentration of $\mathrm{CP}$ to $2.5 \mu \mathrm{g} / \mathrm{ml}$ resulted in a decrease, not statistically significant, in cell viability relative to the control, which was, respectively, in the IOSE 364 cell line: $41 \pm 7.4 \%$, in the SK-OV-3: $79 \pm 6.3 \%$ and in the OVCAR-3: $77 \% \pm 7.5$ (Figure 3). In the IOSE 364 cell line MLT at concentrations of $1 \mathrm{mM}$ and $2 \mathrm{mM}$ with CP caused a significant $(p<0.05)$ decrease in cell survival as compared to the same $\mathrm{CP}(2.5 \mu \mathrm{g} / \mathrm{ml})$. In the case of the SK-OV-3 cell line MLT only at the highest concentration $(2 \mathrm{mM})$ with CP reduced cell survival $(p<0.001)$ compared to CP $(2.5 \mu \mathrm{g} / \mathrm{ml})$ alone, in contrast to the tumor cell line OVCAR-3, where MLT already at a concentration of $0.5 \mathrm{mM}$ with $\mathrm{CP}$ caused a significant $(p<0.01)$ decrease in cell survival in comparison to $\mathrm{CP}(2.5 \mu \mathrm{g} / \mathrm{ml})$ alone. In IOSE 364 and OVCAR-3 higher concentrations of MLT administered with CP resulted in a further, statistically significant $(p<0.001)$, decrease in cell survival as compared to CP $(2.5 \mu \mathrm{g} / \mathrm{ml})$ alone. The lowest percentage of viable cells was observed after incubation of $\mathrm{CP}(2.5 \mu \mathrm{g} \mathrm{ml})$ with MLT at a concentration of $2 \mathrm{mM}$, and the percentage of viable cells was, respectively, in the IOSE 364: $26 \pm 7.8 \%$, in the SK-OV-3: $73 \% \pm 3.6$ and in the OVCAR-3 cell line: $43 \% \pm 8.2$.

Using $\mathrm{CP}$ at the highest concentration of $5 \mu \mathrm{g} / \mathrm{ml}$ resulted in a decrease, not statistically significant, in cell viability relative to the control, which was, respectively in the IOSE line 364: $29 \% \pm 7.7$, in the line SK-OV-3: $51 \% \pm 3.3$, and in the line OVCAR-3: $44 \% \pm 10$ (Figure 4). Significant decreases in cell survival of the IOSE 364 and OVCAR-3 lines were observed after the addition of CP $(5 \mu \mathrm{g} / \mathrm{ml})$ with MLT at the two highest concentrations $(1 \mathrm{mM}$ and $2 \mathrm{mM})$, and the percentage of live cells was, respectively, in the IOSE 364 : $24 \% \pm 5.2$ and $20 \% \pm 5.7$, and in the OVCAR-3 line: $35 \% \pm 5.6$ and $34 \% \pm 8.1$. In the SK-OV-3 cell line, a significant $(p<0.001)$ decrease in cell viability $(36 \% \pm 8.3)$ occurred after the addition of CP $(5 \mu \mathrm{g} / \mathrm{ml})$ with MLT at $2 \mathrm{mM}$.

Evaluation of the effect of luzindol - melatonin receptor antagonist, on the survival of IOSE 364, SK-OV-3 and OVCAR3 cells treated with MLT in combination with $C P$. In order to verify the contribution of melatonin receptors MT1 to the action of MLT in combination with CP in the tested cell lines, luzindole - MT1 melatonin receptor antagonist was used. One concentration of CP $(2.5 \mu \mathrm{g} / \mathrm{ml})$, two concentrations of MLT (1 $\mathrm{mM}$ and $2 \mathrm{mM})$ and three concentrations of luzindole $(1 \mu \mathrm{M}$, $10 \mu \mathrm{M}, 50 \mu \mathrm{M})$ were selected for this study. Pre-incubation of cells with the three tested concentrations of luzindole did not cause significant changes in the activity of different combinations of MLT $(1 \mathrm{mM}$ and $2 \mathrm{mM})$ with $\mathrm{CP}(2.5 \mu \mathrm{g} / \mathrm{ml})$.

Evaluation of interactions of MLT in combination with $C P$ on IOSE 364, SK-OV-3 and OVCAR-3 cell survival. In order to evaluate the type of interactions occurring between MLT 


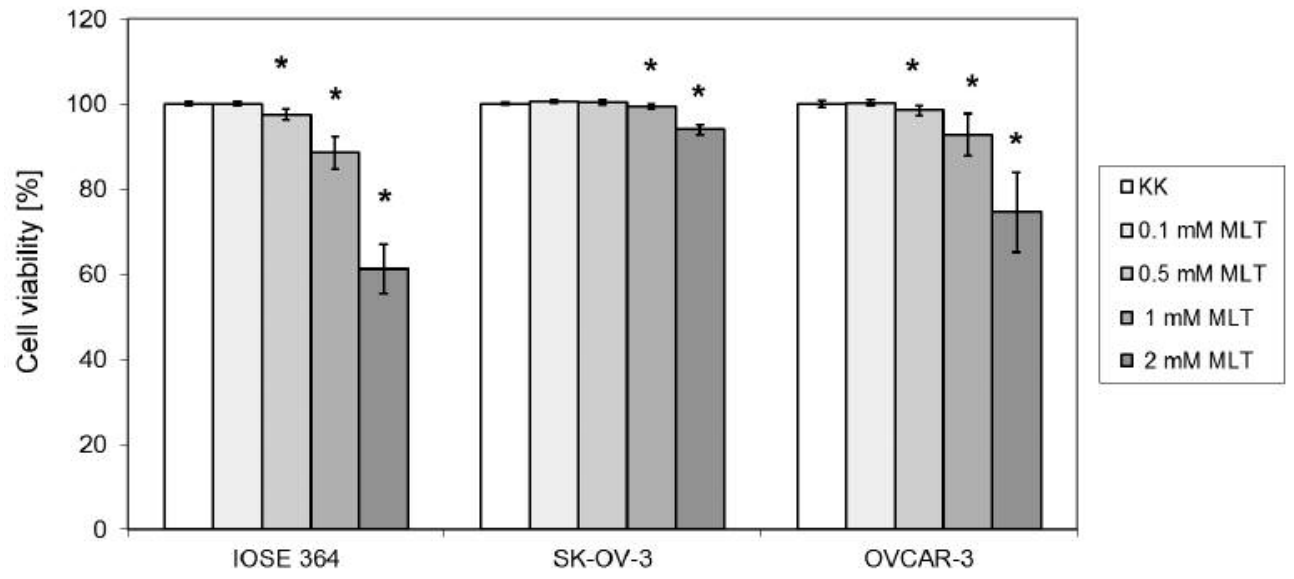

Figure 1. Effect of MLT on IOSE 364, SK-OV-3, OVCAR-3 cell survival. The survival rate of tested cells lines depended on the applied dose of MLT. (KK-control) $* * * v s . K K(p<0,001)$. Values are shown as the mean $\pm s . d ., n=3$.

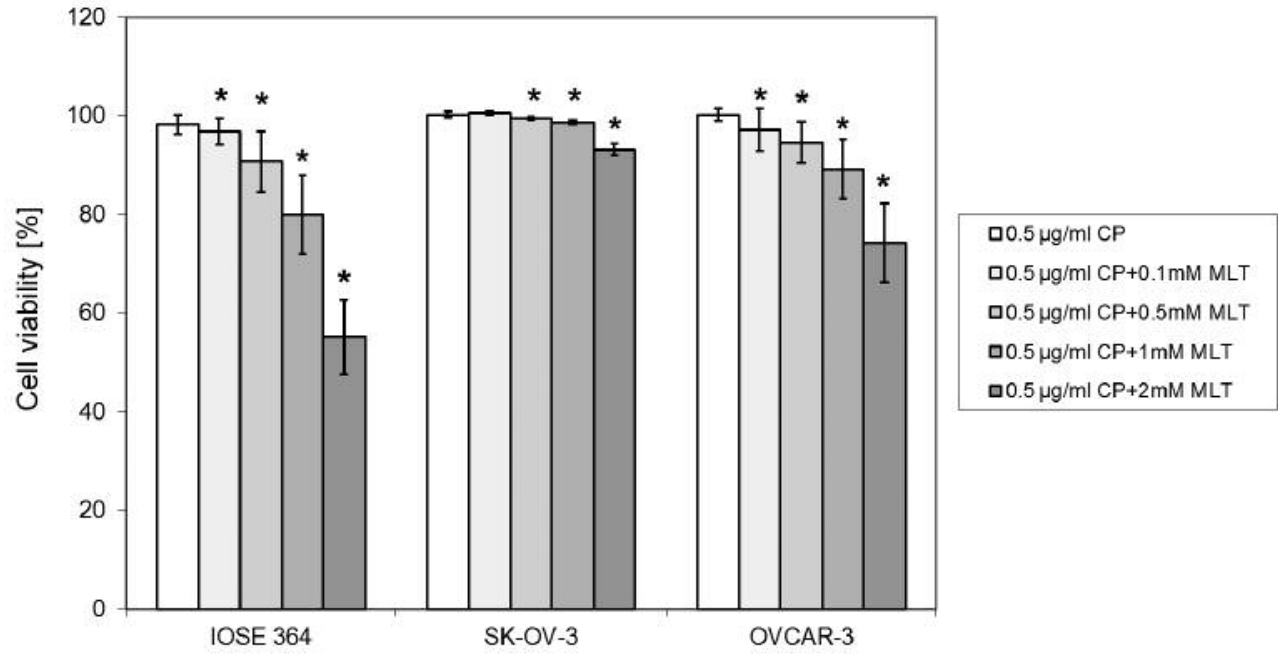

Figure 2. Effect of MLT and CP $(0.5 \mu \mathrm{g} / \mathrm{ml})$ on cell survival of IOSE 364, SK-OV-3, OVCAR-3 lines.**vs. $0,5 \mu \mathrm{g} / \mathrm{ml} C P(p<0.01)$, ***vs. 0,5 $\mu \mathrm{g} / \mathrm{ml}$ $C P(p<0,001)$. Values are shown as the mean $\pm s . d ., n=3$.

and $\mathrm{CP}$ in reducing the survival of treated cells, the drug interaction coefficient was used (CDI) (5). A synergistic effect was observed in the IOSE 364 cell line $(\mathrm{CDI}=0.84)$ and in the SK-OV-3 cell line $(\mathrm{CDI}=0.81)$ using the combination of the highest concentration of MLT ( $2 \mathrm{mM})$ and CP $(5 \mu \mathrm{g} / \mathrm{ml})$, while in the OVCAR-3 line a synergistic effect was observed at the two highest MLT concentrations $(1 \mathrm{mM}$ and $2 \mathrm{mM})$ and $\mathrm{CP}$ at $2.5 \mu \mathrm{g} / \mathrm{ml}$ (CDI was 0.87 and 0.81 , respectively). In all other combinations of MLT and CP, the CDI value was close to one, which indicates an additive effect between the tested compounds.

\section{Discussion}

Ovarian cancer in advanced cases requires the use of platinumbased chemotherapy which has serious side effects $(1,2,31)$. Previous studies have shown that the combination of platinum derivatives with different substances may be an effective therapeutic strategy for the treatment of ovarian cancer $(2,32-$ 35). Among the compounds tested in combination with cytostatics was MLT, which also exhibited antitumor activity $(2,3,36)$. MLT in combination with CP can have synergistic anti-tumor effects on ovarian cancer cells, and decrease the 


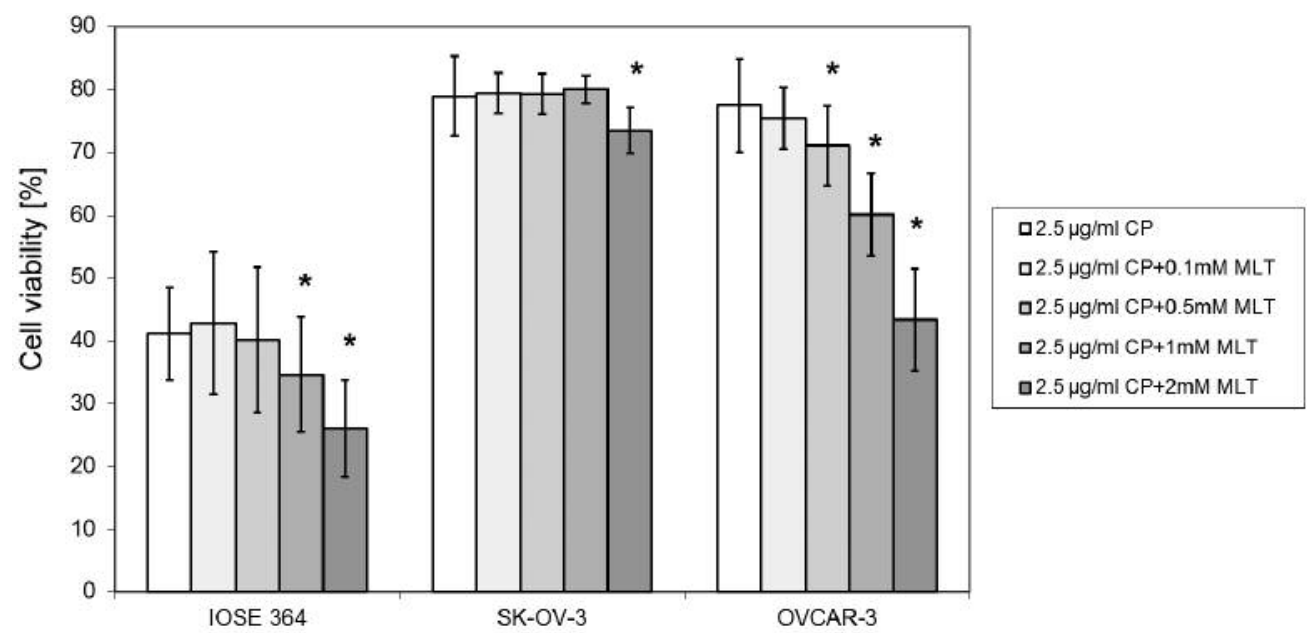

Figure 3. Effect of MLT and CP $(2.5 \mu \mathrm{g} / \mathrm{ml})$ on IOSE 364, SK-OV-3, and OVCAR-3 cell survival. *vs. $2.5 \mu \mathrm{g} / \mathrm{ml} C P(p<0.05)$, ** vs. $2.5 \mu \mathrm{g} / \mathrm{ml} C P$ $(p<0.01), * * * v s .2 .5 \mu \mathrm{g} / \mathrm{ml} \mathrm{CP}(p<0.001)$. Values are shown as the mean \pm s.d., $n=3$.

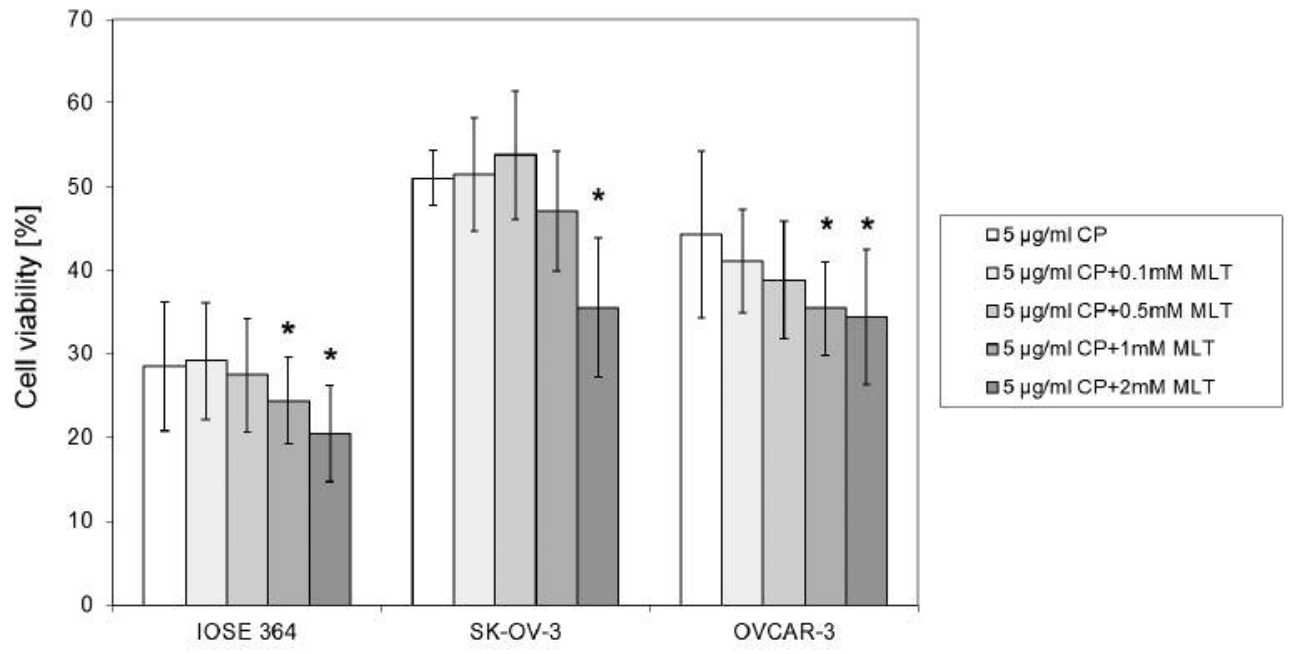

Figure 4. Effect of MLT and CP $(5 \mu \mathrm{g} / \mathrm{ml})$ on IOSE 364, SK-OV-3 and OVCAR-3 cell survival. *vs. $5 \mu \mathrm{g} / \mathrm{ml} C P(p<0.05)$, ** vs. $5 \mu \mathrm{g} / \mathrm{ml} C P(p<0.01)$, $* * * v s .5 \mu \mathrm{g} / \mathrm{ml} C P(p<0.001)$. Values are shown as the mean \pm s.d., $n=3$.

toxicity of the chemotherapeutic agent on normal ovarian epithelial cells (2). There are few studies on the mechanisms of MLT activity and its interaction with CP in ovarian cancer. The tested doses and concentrations of compounds are selective and the results are ambiguous. Accordingly, we evaluated the potential synergistic effect of MLT in combination with $\mathrm{CP}$ on ovarian cancer cells and determined the role of MT1 melatonin receptor in this mechanism.

The antitumor activity of MLT was investigated on different cell lines. In the in vitro model the influence of MLT alone (37-39) and in combination with drugs (40-42) was assessed using a wide range of doses from physiological to pharmacological (43). Data from literature show that the antitumor effect of MLT may vary and depend not only on the used concentration, but also on the type of cells and culture conditions (44, 45). Many studies have been conducted on MCF-7 breast cancer cells. The addition of $1 \mathrm{nM}$ MLT to the MCF-7 cell culture resulted in the inhibition of their growth, increased expression of proapoptotic proteins $\mathrm{p} 53$ and $\mathrm{p} 21$ and reduced their metastatic potential due to increased expression of E-cadherin and $\beta 1$-integrin proteins (46). Additionally, the effect of MLT on 
tumor growth in mice implanted with human breast cancer MCF-7 was also investigated. Administration of MLT to animals resulted in a significant reduction of tumor mass and decreased metastasis in comparison to the control group (47). Farriol et al. have demonstrated an inhibitory effect of MLT on the growth of CT-26 cells from mouse colorectal cancer (48). MLT does not affect cell growth at low doses, as opposed to high millimolar doses, after which significant reductions of DNA synthesis have been observed $(46,48)$. In turn, other researchers assessed the effects of MLT on HepG2 hepatocellular carcinoma by analyzing cell cycle inhibition, apoptosis, and the signaling pathway of the mitogen activated protein kinase (MAPK). MLT given to HepG2 cells at a concentration of $1 \mathrm{mM}$ to $10 \mathrm{mM}$ resulted in dose- and timedependent decreases in the number of cells $(49,50)$.

In this present study we found that MLT at pharmacological concentrations $(0.1 \mathrm{mM}-2 \mathrm{mM})$ after $72 \mathrm{~h}$ of incubation reduced the survival of both the normal line IOSE 364 and ovarian cancer cells SK-OV-3 and OVCAR3 in a dose-dependent manner. Petranka et al. demonstrated that MLT at nanomolar concentrations after $48 \mathrm{~h}$ of incubation reduced BG-1 ovarian adenocarcinoma cell lines by $20-25 \%$ (27). Futagami et al. did not observe any influence of MLT at physiological concentrations (0.001 nM$1 \mu \mathrm{M}$ ) after $132 \mathrm{~h}$ of incubation on the growth of HTOA and OVCAR-3 ovarian cancer cells (28). Treeck et al. showed that MLT has no effect on cell viability of ovarian cancer cell lines, SK-OV-3 and OVCAR-3 in the concentration range 1 $\mathrm{nM}-100 \mathrm{nM}$ and incubation time from 48 to $144 \mathrm{~h}(20)$. In contrast, the studies of Kim et al. on normal ovarian epithelial cells of OSEN and ovarian cancer cells SK-OV-3 showed that a $24 \mathrm{~h}$ incubation with physiological concentrations of MLT (0.5-2 $\mathrm{mM})$ resulted in a decrease in the viability of ovarian cancer cells by approximately $15 \%$ and a slight increase in the percentage of the viability of normal cells (2). The heterogeneity of the obtained results may be due to the different experimental conditions and the use of different assays for cell survival. In many in vitro studies, MLT was tested in combination with anticancer drugs. It has been shown that MLT (10 nM-10 $\mu \mathrm{M})$ in combination with doxorubicin significantly inhibited the growth and enhancement of apoptosis in hepatocellular carcinoma cells HepG2 and Bel-7402 compared to cells treated with chemotherapy alone. Induction of apoptosis was associated with decreased expression of Bcl-2 protein and increased expression of Bax protein and caspase-3 (5). Also in the cell culture of lung carcinoma A-549 and laryngeal carcinoma HEp-2, MLT at pharmacological concentrations strengthened the effect of doxorubicin, thereby reducing the number of cells and intensifying their apoptosis (51). Other experiments have shown synergistic effects of MLT (50 $\mu \mathrm{M}$ $1 \mathrm{mM}$ ), vincristine and ifosfamide in the Ewing's sarcoma cell line SK-N-MC, and the observed synergistic effect was a result of increased apoptosis. MLT in combination with vincristine or ifosfamide caused a significant increase in the activation of caspase-3, -8, -9 and proapoptotic Bid protein (52). The effect of $1 \mathrm{mM}$ MLT on the cytotoxicity and apoptosis induced by three chemotherapeutic agents was also determined: 5-fluorouracil, doxorubicin and cisplatin in the rat pancreatic cancer cell line AR42J. MLT significantly increased the cytotoxicity of the tested drugs (53).

We also assessed the effect of MLT $(0.1 \mathrm{mM}-2 \mathrm{mM})$ in combination with CP $(0.5 \mu \mathrm{g} / \mathrm{ml}-5 \mu \mathrm{g} / \mathrm{ml})$ on the survival of IOSE 364, SK-OV-3 and OVCAR-3 cell lines after $72 \mathrm{~h}$ incubation and determined the type of interaction between these compounds. CP in combination with MLT more intensely decreased the survival of IOSE 364 cells, SK-OV-3 and OVCAR-3 lines than CP alone. As with the MLT alone, the normal cell line IOSE 364 was the most sensitive to $\mathrm{CP}$ and the most resistant was the ovarian cancer line SK-OV-3. The value of the CDI (drug interactions coefficient) indicates synergistic effects on the IOSE 364 and SK-OV-3 lines using the combination of the highest concentration of MLT (2 mM) and $\mathrm{CP}(5 \mu \mathrm{g} / \mathrm{ml})$, whereas in the OVCAR-3 line there are synergistic effects with a mean CP concentration $(2.5 \mu \mathrm{g} / \mathrm{ml})$ and the two highest concentrations of MLT (1 mM and 2 $\mathrm{mM}$ ). In all other MLT and CP combinations, the CDI value indicated the additive effect between the substances which were used. Kim et al. also investigated the effect of the MLT and $\mathrm{CP}$ combination on the survival of ovarian normal-surface epithelial cell line OSEN and SK-OV-3 ovarian carcinoma cell line after $24 \mathrm{~h}$ of incubation (2). They observed a synergistic effect between MLT $(0.5 \mathrm{mM}, 1 \mathrm{mM}$ and $2 \mathrm{mM})$ and CP (80 $\mu \mathrm{M}=24 \mu \mathrm{g} / \mathrm{ml})$ in the SK-OV-3 ovarian carcer cell line. In contrast to the cancer cell line, MLT decreased cytostatic CP activity in normal OSEN cells, demonstrating a protective effect against damage caused by CP in normal cells. Futagami et al. also studied the effect of MLT at the physiological concentrations (maximum $1 \mu \mathrm{M})$, in combination with $\mathrm{CP}(0.5$ $\mu \mathrm{g} / \mathrm{ml})$ on the survival of ovarian cancer cells HTOA and OVCAR-3. MLT increased sensivity to the CP of both ovarian cancer lines (28). The results of both Kim et al. and Futugami et al. indicate that MLT acts synergistically at selected concentrations on SK-OV-3 and OVCAR-3 ovarian carcer cell lines $(2,28)$. The differences in the obtained results may be due to various experimental conditions and survival evaluation methods, as in the case of tests with MLT alone. In this study, it seemed particularly important to use different concentrations of $\mathrm{CP}(0.5 \mu \mathrm{g} / \mathrm{ml}-5 \mu \mathrm{g} / \mathrm{ml})$ compared to the experiments of Kim et al. and Futugami et al. $(2,28)$. Kim et al. used a very high concentration of $\mathrm{CP}$, significantly higher than the therapeutic dose $(0.5 \mu \mathrm{g} / \mathrm{ml})(54)$. The observed differences in the interaction of CP and MLT on normal cells and cancer cells may also result (as in the case of MLT alone) from the differences between cell lines and the high degree of proliferation of immortalized normal cells - IOSE 364. 
Because of the discrepancies between our results and the results of other research groups, it is difficult to accurately determine the range of MLT concentrations that should be used to support the action of the CP.

MLT can act on normal and cancer cells via membrane receptors as well as by mechanisms independent of these receptors (54). In our previous studies, we demonstrated the expression of the MT1 receptor protein in all tested cell lines: IOSE 364, SK-OV-3 and OVCAR-3 (12). The highest level of MT1 receptor expression was observed in normal ovarian epithelial cells IOSE 364, and the lowest in poorly differentiated ovarian cancer cells OVCAR-3 (12). Furthermore, in other types of cancer decreasing MT1 receptor expression with histological grade has been demonstrated (21, 55, 56). Different levels of MT1 protein expression have been seen, i.e. in breast cancer cell lines characterized by an increasing degree of aggressiveness: MCF-7<SK-BR-3<MDAMB-231 (21). In order to investigate the contribution of MT1 receptor in the combined action of MLT with CP, we examined the effect of melatonin receptor antagonists - luzindole on the survival of IOSE 364, SK-OV-3 and OVCAR-3 cells treated with MLT (1 mM and $2 \mathrm{mM})$ in combination with CP $(2,5$ $\mu \mathrm{g} / \mathrm{ml})$. However, the preincubation of cells with luzindole did not significantly alter the effect of MLT in combination with $\mathrm{CP}$ in the investigated cell lines, suggesting that MT1 receptor had no significant role in this experiment. MLT in the presented studies reduced cell survival only at high pharmacological concentrations. Due to the high affinity of MT1 receptor to MLT ( $\mathrm{Kd}=20-40 \mathrm{pmol})$ it can be assumed that this effect is related to the lack of involvement of melatonin membrane receptors in the cytotoxic activity of MLT (57). What is important, many previous studies have shown that MLT is safe in a very wide range of doses $(58,59)$. Similar effects were observed in the human leukemia line HL-60, where the inhibition of cell growth by pharmacological concentrations of the MLT was also unchanged after the addition of luzindol $(10 \mathrm{mM})$ and paclitaxel (PTX) which in general are inhibitors of $\mathrm{G}$ protein-coupled receptors. This may indicate the lack of participation of the $G$ protein-coupled receptors in the above tests (60). These results are different from the results obtained by Kanishi et al., where the effect of MLT on endometrial cancer cells at physiological concentrations was blocked by luzindole (61). However, the results of Carbajo-Pescador et al. performed on liver cancer cell line HepG2, showed that the concentration of MLT is not the only determining factor (49). Preincubation with luzindole $(1 \mu \mathrm{M})$ resulted in partial inhibition of the effect of MLT, used at high pharmacological concentrations (1 mM and $2.5 \mathrm{mM})$, on HepG cell viability, indicating involvement of MT1 receptor (49). Thus, it can be expected that the activation of the MT1 by the MLT is a complex process, probably dependent on many factors: the dose of a MLT, the type of cells used and the level of MT1 expression.
In summary, it was shown that the MLT in pharmacological concentrations decreased the survival of tested cell lines in a dose-dependent manner, the most in normal cells IOSE 364, and the least in cancer cells SK-OV3. In addition, the MLT at the selected concentrations showed synergistic effects in combination with $\mathrm{CP}$, and this effect appears to be independent of the MT1 membrane receptors. The presented results and literature data suggest the possibility of conducting further studies on MLT towards its use as a cisplatin-adjuvant chemotherapeutic agent in ovarian cancer. Although a great amount of research indicates the effect of MLT on the effectiveness of selected chemotherapeutics, there is still no complete explanation of the mechanisms through which the pineal hormone may increase the efficacy of cytostatics.

\section{Acknowledgements}

The results of this study were funded by the Ministry of Science and Higher Education Project for Young Scientsts No. Pbmn 83.

\section{References}

1 Hennessy BT, Coleman RL and Markman M: Ovarian cancer. Lancet 374(9698): 1371-1382, 2009.

2 Kim JH, Jeong SJ, Kim B, Yun SM, Choi DY and Kim SH: Melatonin synergistically enhances cisplatin-induced apoptosis via the dephosphorylation of erk/p90 ribosomal s6 kinase/heat shock protein 27 in sk-ov-3 cells. J Pineal Res 52(2): 244-252, 2012.

3 Shiu SY: Towards rational and evidence-based use of melatonin in prostate cancer prevention and treatment. J Pineal Res 43(1): 1-9, 2007.

4 Hardeland R, Cardinali DP, Srinivasan V, Spence DW, Brown GM and Pandi-Perumal SR: Melatonin - a pleiotropic, orchestrating regulator molecule. Prog Neurobiol 93(3): 350384, 2011.

5 Fan LL, Sun GP, Wei W, Wang ZG, Ge L, Fu WZ and Wang H: Melatonin and doxorubicin synergistically induce cell apoptosis in human hepatoma cell lines. World J Gastroenterol 16(12): 1473-1481, 2010.

6 Altun A and Ugur-Altun B: Melatonin: Therapeutic and clinical utilization. Int J Clin Pract 61(5): 835-845, 2007.

7 Jockers R, Delagrange P, Dubocovich ML, Markus RP, Renault $\mathrm{N}$, Tosini G, Cecon E and Zlotos DP: Update on melatonin receptors: Iuphar review 20. Br J Pharmacol 173(18): 2702$2725,2016$.

8 Danielczyk K and Dziegiel P: mt 1 melatonin receptors and their role in the oncostatic action of melatonin. Postepy Hig Med Dosw (Online) 63: 425-434, 2009.

9 Barrett P, Conway S and Morgan PJ: Digging deep--structurefunction relationships in the melatonin receptor family. J Pineal Res 35(4): 221-230, 2003.

10 Liu J, Clough SJ, Hutchinson AJ, Adamah-Biassi EB, PopovskaGorevski $\mathrm{M}$ and Dubocovich ML: Mt1 and $\mathrm{mt} 2$ melatonin receptors: A therapeutic perspective. Annu Rev Pharmacol Toxicol 56: 361-383, 2016. 
11 Dubocovich ML, Delagrange P, Krause DN, Sugden D, Cardinali DP and Olcese J: International union of basic and clinical pharmacology. Lxxv. Nomenclature, classification, and pharmacology of $\mathrm{g}$ protein-coupled melatonin receptors. Pharmacol Rev 62(3): 343-380, 2010.

12 Jablonska K, Pula B, Zemla A, Kobierzycki C, Kedzia W, Nowak-Markwitz E, Spaczynski M, Zabel M, PodhorskaOkolow M and Dziegiel P: Expression of the mt1 melatonin receptor in ovarian cancer cells. Int J Mol Sci 15(12): 2307423089, 2014.

13 Gerdin MJ, Masana MI, Rivera-Bermúdez MA, Hudson RL, Earnest DJ, Gillette MU and Dubocovich ML: Melatonin desensitizes endogenous $\mathrm{mt} 2$ melatonin receptors in the rat suprachiasmatic nucleus: Relevance for defining the periods of sensitivity of the mammalian circadian clock to melatonin. FASEB J 18(14): 1646-1656, 2004.

14 Gerdin MJ, Masana MI, Ren D, Miller RJ and Dubocovich ML: Short-term exposure to melatonin differentially affects the functional sensitivity and trafficking of the hmt 1 and hmt2 melatonin receptors. J Pharmacol Exp Ther 304(3): 931-939, 2003.

15 Masters A, Pandi-Perumal SR, Seixas A, Girardin JL and McFarlane SI: Melatonin, the hormone of darkness: From sleep promotion to ebola treatment. Brain Disord Ther 4(1): 1000151, 2014.

16 Pandi-Perumal SR, Trakht I, Srinivasan V, Spence DW, Maestroni GJ, Zisapel N and Cardinali DP: Physiological effects of melatonin: Role of melatonin receptors and signal transduction pathways. Prog Neurobiol 85(3): 335-353, 2008.

17 Slominski RM, Reiter RJ, Schlabritz-Loutsevitch N, Ostrom RS and Slominski AT: Melatonin membrane receptors in peripheral tissues: Distribution and functions. Mol Cell Endocrinol 351(2): 152-166, 2012.

18 Tam CW, Mo CW, Yao KM and Shiu SY: Signaling mechanisms of melatonin in antiproliferation of hormone-refractory 22rv 1 human prostate cancer cells: Implications for prostate cancer chemoprevention. J Pineal Res 42(2): 191-202, 2007.

19 Girgert R, Hanf V, Emons G and Gründker C: Membrane-bound melatonin receptor $\mathrm{mt} 1$ down-regulates estrogen responsive genes in breast cancer cells. J Pineal Res 47(1): 23-31, 2009.

20 Treeck O, Haldar C and Ortmann O: Antiestrogens modulate $\mathrm{mt} 1$ melatonin receptor expression in breast and ovarian cancer cell lines. Oncol Rep 15(1): 231-235, 2006.

21 Jablonska K, Pula B, Zemla A, Owczarek T, Wojnar A, Rys J, Ambicka A, Podhorska-Okolow M, Ugorski M and Dziegiel P: Expression of melatonin receptor $\mathrm{mt} 1$ in cells of human invasive ductal breast carcinoma. J Pineal Res 54(3): 334-345, 2013.

22 Srinivasan V, Pandi-Perumal SR, Brzezinski A, Bhatnagar KP and Cardinali DP: Melatonin, immune function and cancer. Recent Pat Endocr Metab Immune Drug Discov 5(2): 109-123, 2011.

23 Slominski AT, Kim TK, Takeda Y, Janjetovic Z, Brozyna AA, Skobowiat C, Wang J, Postlethwaite A, Li W, Tuckey RC and Jetten AM: Ror $\alpha$ and ror $\gamma$ are expressed in human skin and serve as receptors for endogenously produced noncalcemic 20hydroxy- and 20,23-dihydroxyvitamin d. FASEB J 28(7): 27752789, 2014.

24 Reiter RJ, Mayo JC, Tan DX, Sainz RM, Alatorre-Jimenez M and Qin L: Melatonin as an antioxidant: Under promises but over delivers. J Pineal Res 61(3): 253-278, 2016.
25 Tan DX, Manchester LC, Esteban-Zubero E, Zhou Z and Reiter RJ: Melatonin as a potent and inducible endogenous antioxidant: Synthesis and metabolism. Molecules 20(10): 18886-18906, 2015.

26 Dziegiel P, Murawska-Ciałowicz E, Jethon Z, Januszewska L, Podhorska-Okołów M, Surowiak P, Zawadzki M, Rabczyński J and Zabel M: Melatonin stimulates the activity of protective antioxidative enzymes in myocardial cells of rats in the course of doxorubicin intoxication. J Pineal Res 35(3): 183-187, 2003.

27 Petranka J, Baldwin W, Biermann J, Jayadev S, Barrett JC and Murphy E: The oncostatic action of melatonin in an ovarian carcinoma cell line. J Pineal Res 26(3): 129-136, 1999.

28 Futagami M, Sato S, Sakamoto T, Yokoyama Y and Saito Y: Effects of melatonin on the proliferation and cisdiamminedichloroplatinum (cddp) sensitivity of cultured human ovarian cancer cells. Gynecol Oncol 82(3): 544-549, 2001.

29 Kostoglou-Athanassiou I: Therapeutic applications of melatonin. Ther Adv Endocrinol Metab 4(1): 13-24, 2013.

30 Lutz AM, Ray P, Willmann JK, Drescher C and Gambhir SS: 2deoxy-2-[f-18]fluoro-d-glucose accumulation in ovarian carcinoma cell lines. Mol Imaging Biol 9(5): 260-266, 2007.

31 Kalachand R, Hennessy BT and Markman M: Molecular targeted therapy in ovarian cancer: What is on the horizon? Drugs 71(8): 947-967, 2011.

32 Yunos NM, Beale P, Yu JQ and Huq F: Synergism from sequenced combinations of curcumin and epigallocatechin-3-gallate with cisplatin in the killing of human ovarian cancer cells. Anticancer Res 31(4): 1131-1140, 2011.

33 Yunos NM, Beale P, Yu JQ and Huq F: Synergism from the combination of oxaliplatin with selected phytochemicals in human ovarian cancer cell lines. Anticancer Res 31(12): 4283-4289, 2011.

34 Su W, Huang L, Ao Q, Zhang Q, Tian X, Fang Y and Lu Y: Noscapine sensitizes chemoresistant ovarian cancer cells to cisplatin through inhibition of hif-1 $\alpha$. Cancer Lett 305(1): 94-99, 2011.

35 Choi CH, Lee YY, Song TJ, Park HS, Kim MK, Kim TJ, Lee JW, Lee JH, Bae DS and Kim BG: Phase ii study of belotecan, a camptothecin analogue, in combination with carboplatin for the treatment of recurrent ovarian cancer. Cancer 117(10): 2104-2111, 2011.

36 Sookprasert A, Johns NP, Phunmanee A, Pongthai P, Cheawchanwattana A, Johns J, Konsil J, Plaimee P, Porasuphatana $\mathrm{S}$ and Jitpimolmard $\mathrm{S}$ : Melatonin in patients with cancer receiving chemotherapy: A randomized, double-blind, placebo-controlled trial. Anticancer Res 34(12): 7327-7337, 2014.

37 Mediavilla MD, Sanchez-Barcelo EJ, Tan DX, Manchester L and Reiter RJ: Basic mechanisms involved in the anti-cancer effects of melatonin. Curr Med Chem 17(36): 4462-4481, 2010.

38 Sánchez-Hidalgo M, Guerrero JM, Villegas I, Packham G and de la Lastra CA: Melatonin, a natural programmed cell death inducer in cancer. Curr Med Chem 19(22): 3805-3821, 2012.

39 Zhang S, Qi Y, Zhang H, He W, Zhou Q, Gui S and Wang Y: Melatonin inhibits cell growth and migration, but promotes apoptosis in gastric cancer cell line, sgc7901. Biotech Histochem 88(6): 281-289, 2013.

40 Koh W, Jeong SJ, Lee HJ, Ryu HG, Lee EO, Ahn KS, Bae H and Kim SH: Melatonin promotes puromycin-induced apoptosis with activation of caspase- 3 and 5'-adenosine monophosphateactivated kinase-alpha in human leukemia hl-60 cells. J Pineal Res 50(4): 367-373, 2011. 
41 Hermann R, Podhajsky S, Jungnickel $\mathrm{S}$ and Lerchl A: Potentiation of antiproliferative effects of tamoxifen and ethanol on mouse hepatoma cells by melatonin: Possible involvement of mitogen-activated protein kinase and induction of apoptosis. J Pineal Res 33(1): 8-13, 2002.

42 Martín V, García-Santos G, Rodriguez-Blanco J, Casado-Zapico S, Sanchez-Sanchez A, Antolín I, Medina M and Rodriguez C: Melatonin sensitizes human malignant glioma cells against trailinduced cell death. Cancer Lett 287(2): 216-223, 2010.

43 Jung B and Ahmad N: Melatonin in cancer management: Progress and promise. Cancer Res 66(20): 9789-9793, 2006.

44 Rodriguez C, Martín V, Herrera F, García-Santos G, RodriguezBlanco J, Casado-Zapico S, Sánchez-Sánchez AM, Suárez S, Puente-Moncada N, Anítua MJ and Antolín I: Mechanisms involved in the pro-apoptotic effect of melatonin in cancer cells. Int J Mol Sci 14(4): 6597-6613, 2013.

45 Di Bella G, Mascia F, Gualano L and Di Bella L: Melatonin anticancer effects: Review. Int J Mol Sci 14(2): 2410-2430, 2013.

46 Carpentieri A, Díaz de Barboza G, Areco V, Peralta López M and Tolosa de Talamoni N: New perspectives in melatonin uses. Pharmacol Res 65(4): 437-444, 2012.

47 Leon-Blanco MM, Guerrero JM, Reiter RJ, Calvo JR and Pozo D: Melatonin inhibits telomerase activity in the mcf-7 tumor cell line both in vivo and in vitro. J Pineal Res 35(3): 204-211, 2003.

48 Farriol M, Venereo Y, Orta X, Castellanos JM and SegoviaSilvestre T: In vitro effects of melatonin on cell proliferation in a colon adenocarcinoma line. J Appl Toxicol 20(1): 21-24, 2000

49 Carbajo-Pescador S, García-Palomo A, Martín-Renedo J, Piva M, González-Gallego $\mathrm{J}$ and Mauriz JL: Melatonin modulation of intracellular signaling pathways in hepatocarcinoma hepg2 cell line: Role of the mt1 receptor. J Pineal Res 51(4): 463-471, 2011.

50 Martín-Renedo J, Mauriz JL, Jorquera F, Ruiz-Andrés O, González P and González-Gallego J: Melatonin induces cell cycle arrest and apoptosis in hepatocarcinoma hepg2 cell line. J Pineal Res 45(4): 532-540, 2008.

51 Fic M, Podhorska-Okolow M, Dziegiel P, Gebarowska E, Wysocka T, Drag-Zalesinska $M$ and Zabel M: Effect of melatonin on cytotoxicity of doxorubicin toward selected cell lines (human keratinocytes, lung cancer cell line a-549, laryngeal cancer cell line hep-2). In Vivo 21(3): 513-518, 2007.

52 Casado-Zapico S, Rodriguez-Blanco J, García-Santos G, Martín V, Sánchez-Sánchez AM, Antolín I and Rodriguez C: Synergistic antitumor effect of melatonin with several chemotherapeutic drugs on human ewing sarcoma cancer cells: Potentiation of the extrinsic apoptotic pathway. J Pineal Res 48(1): 72-80, 2010.
53 Uguz AC, Cig B, Espino J, Bejarano I, Naziroglu M, Rodríguez $\mathrm{AB}$ and Pariente JA: Melatonin potentiates chemotherapyinduced cytotoxicity and apoptosis in rat pancreatic tumor cells. J Pineal Res 53(1): 91-98, 2012.

54 Kang EJ, Jung H, Woo OH, Park KH, Woo SU, Yang DS, Kim AR, Lee JB, Kim YH, Kim JS and Seo JH: Ykl-40 expression could be a poor prognostic marker in the breast cancer tissue. Tumour Biol 35(1): 277-286, 2014.

55 Nakamura E, Kozaki K, Tsuda H, Suzuki E, Pimkhaokham A, Yamamoto G, Irie T, Tachikawa T, Amagasa T, Inazawa J and Imoto I: Frequent silencing of a putative tumor suppressor gene melatonin receptor 1 a (mtnr1a) in oral squamous-cell carcinoma. Cancer Sci 99(7): 1390-1400, 2008.

56 Collins A, Yuan L, Kiefer TL, Cheng Q, Lai L and Hill SM: Overexpression of the $\mathrm{mt} 1$ melatonin receptor in mcf-7 human breast cancer cells inhibits mammary tumor formation in nude mice. Cancer Lett 189(1): 49-57, 2003.

57 Carbajo-Pescador S, Martín-Renedo J, García-Palomo A, Tuñón MJ, Mauriz JL and González-Gallego J: Changes in the expression of melatonin receptors induced by melatonin treatment in hepatocarcinoma hepg2 cells. J Pineal Res 47(4): 330-338, 2009.

58 Jahnke G, Marr M, Myers C, Wilson R, Travlos G and Price C: Maternal and developmental toxicity evaluation of melatonin administered orally to pregnant sprague-dawley rats. Toxicol Sci 50(2): 271-279, 1999.

59 Seabra ML, Bignotto M, Pinto LR and Tufik S: Randomized, double-blind clinical trial, controlled with placebo, of the toxicology of chronic melatonin treatment. J Pineal Res 29(4): 193-200, 2000.

60 Rubio S, Estévez F, Cabrera J, Reiter RJ, Loro J and Quintana $\mathrm{J}$ : Inhibition of proliferation and induction of apoptosis by melatonin in human myeloid hl-60 cells. J Pineal Res 42(2): 131-138, 2007.

61 Kanishi Y, Kobayashi Y, Noda S, Ishizuka B and Saito K: Differential growth inhibitory effect of melatonin on two endometrial cancer cell lines. J Pineal Res 28(4): 227-233, 2000.

Received June 19, 2017

Revised July 14, 2017

Accepted July 17, 2017 